\title{
Analysing Purchasing Intention of Counterfeit Sportswear Products in Klang Valley, Malaysia
}

\author{
SelvanPerumal $^{1}$, Azizul Rahman Sapihan ${ }^{2}$ \\ ${ }^{a}$ School of Business Management,Universiti Utara Malaysia, Malaysia \\ ${ }^{B}$ Intan, MALAYSIA
}

\begin{abstract}
Increased trading activity involving counterfeit goods was worrying and had become a main intimidation towards the economy. Fast innovative advancements, growth in sportswear industry and increased in government effort in promoting healthy lifestyle have helped foster the development of this issue. Relationship between consumers purchasing intention towards counterfeit sportswear, attitude towards counterfeit sportswear, subjective norms and perceived behavior control were analyzed in the context of Malaysia using Theory of Planned Behavior as the underpinning theory with moderate impact of moral judgement. Data was collected through self-administered questionnaires that were distributed to 454 respondents at shopping malls and night markets in Klang Valley. This paper used Pearson Correlation Coefficient and Multiple Linear Regression analysis to study the purchasing behavior towards counterfeit sportswear. Results showed that except for perceived behavior control which shows insignificant relationship, all other independent variables were significantly and positively related to the dependent variable. This study could help related parties such as the government agencies, genuine marketers and product producers to understand better why consumers prefer counterfeit sportswear products.
\end{abstract}

Keywords: Attitude, Counterfeit, Purchase Intention, Sportswear

\section{Introduction}

Counterfeiting is one of the wildest growing economic crimes globally. It intimidates the economies of established and emerging countries alike, harms new investment, and progressively endangers public health and safety. Developments in technology have permitted counterfeiters to produce improved copies of products and packaging. Today, an enormous range of items are counterfeited, including clothing, jewelry, movies, medicines, car parts, fragrance and agrochemicals. Counterfeit products can be characterized as a product that is almost equal to the original product and produced by the producer, without permission of the copyright owners of the product concerned (Bian and Veloutsou, 2007; Chaudhry and Walsh, 1996). Well known and famous products are often targeted to be counterfeit. This is due to the high demand for these famous products. This is because of items that don't have trademarks are less engaging and would not be profoundly sought after, and endeavors of forging the items are meaningless. According to Avery (2008) and Farmosa (2011), counterfeit of clothing, both fashion and sportswear, is very rampant and is one of the most commonly and easily imitated product in the sports industry. According to Groosman and Shapiro (1988), counterfeit can be separated into two classes that are misleading and non-tricky counterfeit. In case of counterfeit sporting goods, it becomes a serious danger to genuine industries especially when customers intentionally buy them because it is so easy to replicate due to low level of technicality in producing the product (Transcrime, 2010).

According to Organization for Economic Cooperation \& Development (OECD) report on the economic impact of counterfeit shows that the drawback from the sportswear industry turning into a fashion industry has attracted counterfeiters. Firstly, this is because the counterfeit sportswear is easy to produce because it was a straightforward production by using grey market channel. Second, it is easy to imitate because it is always connected to big events such as the World Cup or another major event where counterfeit traders can concentrate on producing a huge amount of fake sportswear. The third is demand on the counterfeit sportswear mostly is from young generation because they are the one who most likely to buy fake sportswear. Counterfeiting certainly impacts legitimate businesses, causing loss of sales, loss of brand trust and value and will ultimately low on profits. However, in an interrelated economy, the impact will also go to governments and consumers. Governments see lower charge salaries and higher cost on welfare, wellbeing administrations and wrongdoing anticipation. Purchasers get lesser quality items that are unregulated and hazardous. Furthermore, as commercial ventures endure mediocre income and harmed brands, they need to cut employments and lessen venture and will prompt lower monetary development.Even though the counterfeit sportswear issue has become a serious issue, to our knowledge, there has been little discussion on sportswear as a target of counterfeit especially in Malaysia. The issue is why the demand for the counterfeit sportswear such as jerseys, shoes and others still increase as it is reflects on the number of cases that has been taken by Ministry of Domestic Trade Cooperative \& Consumerism Enforcement Division. Are there any factors apart from lower prices, brand names, scarcity, country of origin or 
quality that effect the increasing demand of counterfeit sportswear? Previous study by numerous researchers has used TPB as their base theory to explain individuals' behavioral intention such as Chiu, Lee \& Won (2014); Jirotmontree (2013); Alfadl, Ibrahim, \&Hassali (2012); Yoon (2011) and Chen, Pan, \& Pan (2009). Consequently, in perspective of this gap, this study is developed to investigate and comprehend the connections between the attitude, subjective norms and perceived behavior control of shoppers in Malaysia and the purchasing intention on counterfeit sportswear. The producer and manufacturer of genuine product can look into the consumers' action by understanding factors that influencing the disposition of consumers towards counterfeit sportswear.

\section{Theory of Planned Behavior}

Human behavior is quite difficult to describe. That is why many of the scholars have been focusing on this issue as an attempt to understand people's behavior. Therefore, several previous studies used numerous approaches to envisage intentions that are extensively used in consumer behavioral intention research. The Theory of Planned Behavior is a decently looked into expectation display that has been effective in determining and illuminating conduct over a wide variety of areas (Chiu, Lee, \& Won, 2014). The Theory of Planned Behavior (TPB) was initially presented by Azjen in 1985 and serves as an expansion of the Theory of Reasoned Action (TRA) (Alam, Ahmad, Ahmad \&Hashim, 2011). Utilizing TPB, a choice to be made in understanding to conduct, for example, buying counterfeit sportswear can be anticipated by a singular's plan to perform the activity reflected by his conduct specifically (Ajzen, 1985, 1991). The TPB model has been applied in varied settings in an effort to understand a number of different behaviors in which people engage (Bailey, 2006). It was applied in the context of M-Commerce (Mishra, 2014), online privacy facebook (Saeri, Ogilvie, La Macchia, Smith \& Louis, 2014), and vocational guidance entrepreneurship (Kautonen, van Gelderen\&Tornikoski, 2013), fair trade (Ozcaglar-Toulouse, Shiu\& Shaw, 2006) and retail employee theft (Bailey, 2006). Penz and Stottinger (2008) applied the theory as a valuable instrument for model development in the context of the purchase behavior for fake products. They found that the intention to purchase counterfeits impacts the behavior of purchasing counterfeits significantly.TPB advocates that attitude is the significant determinant of conduct. Utilizing the exploration demonstrate over, the researcher will look at whether the variables will at last be changed over into plan that leads buyer to buy counterfeit sportswear or to stay far from it. Hence, the obtaining inclination of shopper towards counterfeit sportswear can be followed back to the roots under TPB model, which is the thing that authentic sportswear advertisers might want to figure out. As in many other behavioral purviews, the theory of planned behavior has established to be a valuable theoretical and methodological framework for the study of consumer behavior (Ajzen, 2008)

The attitude toward behavior is defined as a person's evaluation about the consequences of performing the behavior. In another word, it refers to one's constructive or destructive approaches around doing the target demeanour (Yahyapour, 2008). In this context, the researcher tries to discover the attitude of consumer toward counterfeit sportswear. So, the subsequent propositions are projected:

H1: Consumer attitude towards purchase counterfeit sportswear is positively influence purchasing intention towards counterfeit sportswear.

The subjective norm refers to the perceived influence of social pressure that may affect a person's intention to perform or not perform the behavior (Sayar\& Wolfe, 2007). According to the definition of the subjective norm the items related to this variable will be tested to show the impact of social influence, recommendation by others on counterfeit sportswear and cultural belief on consumer's intention to purchase counterfeit sportswear. Therefore, the following hypotheses are proposed:

H 2: Subjective norms are positively influence purchasing intention towards counterfeit sportswear.

According to Chiu et al. (2014), perceived control behavior reflects a person's awareness of the ease or difficulty of fulfilling the behavior in question. It concerns beliefs about the existence of control factors that may enable or hamper that behavior. All these variables are expected to influence consumers' intention to purchase counterfeit sportswear. Therefore, the following hypotheses are proposed:

H3: Perceived behavior control is positively influence purchasing intention towards counterfeit sportswear.

\section{Measurements and Research Instruments}

The study utilized quantitative approach and the hypotheses were tested carefully using statistics data. The researcher used cross-sectional study to study particular phenomenon such as Malaysian consumers' purchasing intention towards counterfeit sportswear at a particular time (Saunders, Lewis, \& Thornhill, 2009). The respondents were selected using simple random sampling and a self-administered questionnaire was distributed to all participants during a mall intercept in selected shopping malls in Klang Valley. The unit of analysis for this study comprised individual consumers aged 15 years and above. The questionnaire contained two sections. The first section was designed to gather information about the sample's personal information. The second section requested the respondents to indicate on a five-point Likert-type scale, ranging from (1) 
"strongly disagree" to (5) "strongly agree", their take on the questions being asked. A total of 768 selfadministered questionnaires were distributed through mall intercept. Data collection was performed during weekdays and weekends. The random selection was done, by approaching the consumer that enters the shopping mall by selecting every fifth customer that pass by. All the hardcopy data were entered manually using SPSS version 22. A total of 454 responses were usable and being used for subsequent analysis. Thus, the effective response rate is 59 percent. In the process of coding, the orderable options from Strongly Disagree to Strongly Agree in the five-point Likert Scale has been coded from ' 1 ' to ' 5 '. This coding meant that a low value represented a low level for the variable (e.g. 1 = Strongly Disagree) while higher values indicated higher level of the variables. The alpha values for the present study also were calculated to assess the internal consistency reliabilities of the scales. For the Attitude and Subjective norms, the results indicate acceptable values respectively .90 and .75 , while Perceived behavior is 71 . Inter-correlation between variables was done, where the values of correlation coefficients for all the three variables are exceeded .50 and below .80 and significantly correlated

\section{Data Analysis and Results}

Table 1 indicates the demographic profile of the participants. The respondents consisted of 276 female with percentage of $60.8 \%$ whereas the balances of 178 respondents were male with the percentage of $39.2 \%$. Concerning the age of the respondents, $(80.8 \%)$ represent $15-24$ years old, $(12.8 \%)$ represents 25 to 34 years old, $(4.4 \%)$ represents 35 to 44 years old, (1.3\%) represents 45 to 54 years old and $(0.7 \%)$ represents those above 55 years old. With regards to qualifications of the respondents, majority of respondents have completed Secondary certificate $(33 / 7 \%)$ and $(28 \%)$ respondents have Diploma and $(27.1 \%)$ completed Degree. As shown, majority of the participants were female $(60.8 \%)$. Finally, all the respondent were asked on their sportswear preference of counterfeit product and most of the respondent choose clothes as their most preferred counterfeit product $(39.6 \%)$ and shoes as their second preference at $32.8 \%$. This shows that clothing and footwear was a key focus for the consumers to purchase counterfeit goods as compared to other items such as bags, hats and sunglasses.

Table 1.0 Profile of Respondents

\begin{tabular}{|c|c|c|c|}
\hline Item & Classification & Frequency & Percentage \\
\hline \multirow[t]{2}{*}{ Gender } & Male & 178 & 39.2 \\
\hline & Female & 276 & 60.8 \\
\hline \multirow[t]{5}{*}{ Age } & $15-24$ years old & 367 & 80.8 \\
\hline & $25-34$ years old & 58 & 12.8 \\
\hline & $35-44$ years old & 20 & 4.4 \\
\hline & $45-54$ years old & 6 & 1.3 \\
\hline & 55 years and above & 3 & 0.7 \\
\hline \multirow[t]{5}{*}{ Educational qualification } & SPM/STPM & 153 & 33.7 \\
\hline & Diploma & 127 & 28 \\
\hline & Bachelor's degree & 123 & 27.1 \\
\hline & Master & 4 & 0.9 \\
\hline & Others & 46 & 10.1 \\
\hline \multirow{7}{*}{$\begin{array}{ll}\text { ounterfeit } & \text { Sportswear } \\
\text { Preferences } & \end{array}$} & Shoes & 149 & 32.8 \\
\hline & Clothes & 180 & 39.6 \\
\hline & Bag \& Backpacks & 34 & 7.5 \\
\hline & Fitness \& Training Gear & 32 & 7.0 \\
\hline & Hats \& Caps & 12 & 2.6 \\
\hline & Sunglasses & 10 & 2.2 \\
\hline & Others & 37 & 8.1 \\
\hline
\end{tabular}

\section{Multiple Regressions}

Table 2 presents the empirical evidence on the relationship between attitude, subjective norms, perceived behavior control and purchase intentions.

Table 2: Summary of Multiple Regression Result for Attitude, Subjective Norms and Perceived Behavior Control

\begin{tabular}{|l|l|l|l|l|l|l|}
\hline Variable & $\begin{array}{l}\text { Coefficient } \\
\text { B }\end{array}$ & $\begin{array}{l}\text { Standardized } \\
\text { Coefficient Beta }\end{array}$ & T-value & R2 & Adjusted R2 & F-value \\
\hline Constant & .572 & & 4.444 & .596 & .593 & $221.319^{* *}$ \\
\hline Attitude & .574 & $.607^{* *}$ & 15.400 & & & \\
\hline Subjective Norms & .195 & $.207^{* *}$ & 5.062 & & & \\
\cline { 1 - 3 } $\begin{array}{l}\text { Perceived Behavior } \\
\text { Control }\end{array}$ & .044 & .043 & 1.349 & & & \\
\hline
\end{tabular}

** Significant at $\alpha<0.01$ level; *Significant at $\alpha<0.05$ level. 
The regressions analysis reveals that th independent variable namely, attitude, subjective norms and perceived behavior control that explain 59.6\% $(\mathrm{R} 2=.596)$ of the variance in behavioral intention and the standardized coefficient Beta $(\beta)$ for attitude towards counterfeit sportswear was significant and positive, showing that there was a positive linear relationship between attitude towards counterfeit sportswear and purchase intention $\left(\beta=.607^{* *}, \mathrm{p}<0.01\right)$. This supports the research hypotheses $(\mathrm{H} 1)$ that stated that there was a significant relationship between consumer attitude to purchase counterfeit sportswear and purchasing intention towards counterfeit sportswear.Standardized coefficient Beta $(\beta)$ for subjective norms was significant and positive, $(\beta=.207 * *, p<0.01)$ supporting the research hypothesis $(\mathrm{H} 2)$ that states there was a significant relationship between consumer subjective norms and purchasing intention towards counterfeit sportswear. Finally, the standardized coefficient Beta $(\beta)$ for perceived behavior control is positive but insignificant $\left(\beta=.043^{*}, p>0.05\right)$ not supporting the research hypothesis $(\mathrm{H} 3)$ that state there was a significant relationship between consumer perceived behavior control and purchasing intention towards counterfeit sportswear.

\section{Discussion And Conclusion}

According to $\mathrm{H} 1$, consumer attitude is positively influence purchasing intention towards counterfeit sportswear. The finding of this dimension had a positive and significant relationship with purchase intention towards counterfeit sportswear $(\beta=.607, \mathrm{p}<0.01)$. This was the highest value of beta in the model which implies that attitude towards purchasing counterfeit sportswear has the strongest influence on consumer's purchasing intention on counterfeit sportswear. The more favorable consumer's attitude towards purchasing counterfeit sportswear was, the more likely the consumer intention to purchase counterfeit sportswear. In other words, consumers who display high attitudes on counterfeit purchases were more likely to purchase counterfeit sportswear in the future. This result of this study was similar to other studies that confirming attitude's importance and considerable influence on consumer's purchase intention on counterfeit product (Ang et al., 2001; Kwong et al., 2003; Penz and Stottinger, 2005; Wang et al., 2005). Therefore, the result supported the hypothesis (H1). In addition, the findings also consistent with the theory of planned behavior that stated attitude was one of the main predictors of behavioral intention.

The second research question dealt with the relationship between subjective norms and purchase intention. H2 stated, subjective norms are positively influence purchasing intention towards counterfeit sportswear. The study found that subjective norms were significantly and positively related to purchasing intention $\left(\beta=.207^{* *}, \mathrm{p}<0.01\right)$. The result was supported by previous studies that proved the influence of subjective norms on intention to purchase counterfeit sporting goods (Chiu, Lee, \& Won, 2014). Previous study by Matos, Ituassu\& Rossi (2007) stated that subjective norms who representing the social influence also contributed towards consumer intention to purchase counterfeit product.The third research question dealt with the relationship between Perceived Behavior Control and purchase intention. H3 stated that "perceived behavior control positively influence purchasing intention towards counterfeit sportswear". The study found that Perceived Behavior Control make no significant relationship with purchase intention $(\beta=.043, \mathrm{p}>0.05)$. This was similar case on previous study by Alam et al. (2011) constituted that there was no direct and significant relationship between perceived behavior controls with the intention to purchase pirated software. The reason on the insignificant maybe because of the age of the respondent that mostly young students that have plenty of knowledge on pirated product that may consider little opinion on other people and merely base on their own experience and knowledge.

This study has made a huge commitment to the academicians, advertisers and producers of marked authentic merchandise and also contributed to the knowledge of government agencies such as Ministry of Domestic Trade, Cooperatives and Consumerism (MDTCC). The results were consistent with the findings of the Theory of Planned Behavior, which said that attitude and subjective norms were important variables in predicting behavioral intention. However, consumers' perceived behavior control was found to be insignificant towards consumers' purchase intention on counterfeit sportswear. It was found that attitude was the strongest factors that determine consumers' purchase intention towards counterfeit sportswear. This implies that there is very much that needs to be done in order to change the cultural norms of Malaysians that counterfeit is good or even acceptable. In reality, counterfeiting destroys an economy and does not benefit anybody in the long term. Therefore it can clearly state that there is a need to change the perception of consumers in order to deter such thinking. Parents should educate their child at an early age and should seek to avoid promote counterfeit in the household as children look to them as role models. The overall findings of the analysis and understanding of the influence of the variables on consumer intention to purchase counterfeit sportswear helps and provide producers of genuine sportswear products on understanding why consumers prefer purchasing counterfeit sportswear. Thus, they can strengthen their products' marketability and develop a new strategy. It is importance for producers to understand the consumers' perspectives. Finally, the study answered the research questions and accomplished its objectives and supported the notion of the theory of planned behavior on purchasing intention towards counterfeit sportswear in Malaysia. 


\section{References}

[1]. Ajzen, I. (1985). From intentions to actions: A theory of planned behavior. In J. Kuhl \& J. Beckman (Eds.), Action control: From cognition to behavior (11-39). Heidelberg: Springer.

[2]. Ajzen, I. (1991). The theory of planned behavior. Organizational Behavior and Human Decision Processes, 50, $179-211$.

[3]. Ajzen, I. (2008). Consumer attitudes and behavior. In C. P. Haugtvedt, P. M. Herr \& F. R. Cardes (Eds.), Handbook of Consumer Psychology (525- 548). New York: Lawrence Erlbaum Associates.

[4]. Ajzen, J. and Fishbein, M. (1980). Understanding Attitudes and Predicting Social Behavior, Prentice Hall, NJ.

[5]. Alam, S., Ahmad, A., Ahmad, M., \& Hashim, N. (2011). An empirical study of an extended theory of planned behavior model for pirated software purchase. World Journal of .... Retrieved from http://wbiaus.org/10. Nik (NEW).pdf

[6]. Alfadl, A. A., Ibrahim, M. I. M., \& Hassali, M. A. (2012). Consumer behaviour towards counterfeit drugs in a developing country. Journal of Pharmaceutical Health Services Research, 3(3), 165-172.

[7]. Ang, S. H., Cheng, P. S., Lim, E. A., \&Tambyah, S. K. (2001). Spot the difference: Consumer responses towards counterfeits. Journal of Consumer Marketing, 18(3), 219-235.

[8]. Avery, P. (2008). The economic impact of counterfeiting and piracy. OECD Publishing

[9]. Bailey, A. A. (2006). Retail employee theft: A theory of planned behavior perspective. International Journal of Retail \& Distribution Management, 34(11), 802-816.

[10]. Bian, X., \&Veloutsou, C. (2007).Consumers' attitudes regarding non-deceptive counterfeit brands in the UK and China.Journal of Brand Management, 14(3), 211-222.

[11]. Chaudhry, P. E., \& Walsh, M. G. (1996). An assessment of the impact of counterfeiting in international markets: the piracy paradox persists. The Columbia Journal of World Business, 31(3), 34-48.

[12]. Chen, M.-F., Pan, C.-T., \& Pan, M.-C. (2009). The joint moderating impact of moral intensity and moral judgment on consumer's use intention of pirated software. Journal of Business Ethics, 90(3), 361-373. doi:10.1007/s10551-009-0046-8

[13]. Chiu, W., Lee, K.-Y., \& Won, D. (2014). Consumer behavior toward counterfeit sporting goods. Social Behavior and Personality, 42(4), 615-624. doi:10.2224/sbp.2014.42.4.615

[14]. Formosa, N. (2011). Brands push to stem flow of fake product. Bicycle Retailer \& Industry News, 20(17), 1-33.

[15]. Grossman, G. M., \& Shapiro, C. (1988).Foreign counterfeiting of status goods. NBER Working Paper Series, Cambridge: NBER Publishing.

[16]. Jirotmontree, A. (2013). Business ethics and counterfeit purchase intention: A comparative study on Thais and Singaporeans. Journal of International Consumer Marketing, 25(4), 281-288.

[17]. Kautonen,T., van Gelderen, M., \&Tornikoski, E. T. (2013). Predicting entrepreneurial behaviour: A test of the theory of planned behaviour.Applied Economics, 45(6), 697-707. doi:10.1080/00036846.2011.610750.

[18]. Kwong, Kenneth K., Oliver H. M. Yau, Jenny S. Y. Lee, Leo Y. M. Sin, and Alan C. B. Tse. 2003. The effects of attitudinal and demographic factors on intention to buy pirated CDs: The case of Chinese consumers. Journal of Business Ethics,47, 223-35.

[19]. Mishra, S. (2014). Adoption of M-commerce in India: Applying Theory of Planned Behaviour Model. Journal of Internet Banking \& Commerce, 19(1), 1-17.

[20]. Nunnally, J.C. (1978). Psychometric Theory. New York: McGraw-Hill.

[21]. Ozcaglar- Toulouse, N., Shiu, E., \& Shaw, D. (2006). In search of fair trade: ethical consumer decision making in France. International Journal of Consumer Studies, 30(5), 502-514.

[22]. Penz, E., \&Stottinger, B. (2005). Forget the" real" thing-take the copy! An explanatory model for the volitional purchase of counterfeit products.Advances in consumer research, 32, 568.

[23]. Penz, E., \&Stöttinger, B. (2008). Original brands and counterfeit brands - do they have anything in common? Journal of Consumer Behaviour, 7(2), 146-163.

[24]. Piaw, C. Y. (2013). Mastering Research Statistics, Malaysia.McGrraw-Hill (Malaysia) Sdn. Bhd,

[25]. Ratnasingam, J. K., \& Ponnu, C. H. (2008). The influence of consumers' moral intensity, perceived risks and moral judgment in purchasing pirated software. Communications of the IBIMA, 1, 47-61.

[26]. Saeri, A. K., Ogilvie, C., La Macchia, S. T., Smith, J. R., \& Louis, W. R. (2014).Predicting Facebook users' online privacy protection: risk, trust, norm focus theory, and the Theory of Planned Behavior.Journal of Social Psychology, 154(4), 352-369.

[27]. Saunders, M., Lewis, P., \& Thornhill, A. (2009).Research Methods for business student (5th Ed.) FT Essex: Prentice Hall.

[28]. Sayar, C., \& Wolfe, S. (2007). Internet banking market performance: Turkey versus the UK. International Journal of Bank Marketing, 25(3), 122-41.

[29]. Schiffman, L. G., \&Kanuk, L. L. (2004).Customer behavior. New Jersey: Prestice Hall.

[30]. Transcrime. (2010). Anti-brand counterfeiting in the EU:Report on international and national existing standards. Milan, Italy: Joint Research Centre on Transnational Crime.

[31]. Wang, F., Zhang, H., Zang, H., \& Ouyang, M. (2005). Purchasing pirated software: an initial examination of Chinese consumers. Journal of Consumer Marketing, 22(6), 340-351.

[32]. Yahyapour, N. (2008). Determining factors affecting intention to adopt banking recommender system.Master's Thesis, Division of Industrial Marketing and E-commerce, Lulea University of Technology.

[33]. Yoon, C. (2011). Theory of planned behavior and ethics theory in digital piracy: An integrated model. Journal of Business Ethics, $100,405-417$ 